\title{
Karakteristik Penyebaran Api Ketika Terjadi Kebakaran Berbasis Metode FDS (Fire Dynamics Simulator) pada Parkiran Sepeda Motor Kampus A Universitas Negeri Jakarta
}

\author{
Pratomo Setyadi \\ Program Studi Pendidikan Teknik Mesin FT Universitas Negeri Jakarta \\ pratomo_setyadi@yahoo.com
}

\begin{abstract}
ABSTRAK
Penelitian ini dilatar belakangi karena melihat kondisi bangunan parkiran depan Kampus A Universitas Negeri Jakarta yang pembangunan tersendat tetapi sudah dipergunakan untuk khayalayak di khawatirkan dapat membahayakan penghuni, dan karyawan yang bekerja di gedung parkiran tersebut apabila terjadi kebakaran. Penelitian ini bertujuan untuk menentukan kriteria bahaya kebakaran pada parkiran sepeda motor kampus A UNJ. Dalam penelitian ini digunakan Software Fire Dynamics Simulator Version 5.0 untuk membuat suatu pemodelan kebakaran berdasarkan titik awal nyala api dan arah angin.

Pada penelitian ini akan membahas tentang perkembangan api dimana perkembangan api tersebut akan direpresentasikan oleh HRR (Heat Release Rate), burning rate, dan visualisasi dari masing-masing simulasi. Langkah ini sangat menguntungkan karena dapat mengetahui bagaimana penyebaran api saat terjadi kebakaran dan seberapa bahaya kebakaran yang disimulasikan. Dengan adanya fire modelling ini dapat menjadi pendekatan engineering praktis untuk memberikan peninjauan tambahan terhadap aspek keselamatan kebakaran pada gedung parkiran kampus A Univeristas Negeri Jakarta. Dari hasil penelitian ini dapat disimpulkan bahwa cepatnya penyebaran api dipengaruhi titik awalnya api, kecepatan dan arah angin. Dimana semakin besar nilai HRR maka semakin besar pula nilai burning rate yang didapatkan dan semakin besar pula tingkat kebakaran yang terjadi.
\end{abstract}

Kata Kunci: Fire Dynamics Simulator, api, temperatur, Heat Release Rate(HRR), burning rate

\section{PENDAHULUAN}

Gedung bertingkat saat ini semakin banyak bermunculan di berbagai kota besar di Indonesia. Keterbatasan lahan membuat masyarakat ataupun instansi pemerintah maupun swasta berlomba membangun gedung bertingkat baik untuk perkantoran, pemukiman dalam bentuk rumah susun atau apartement dan juga untuk sarana umum. Kebutuhan ruang gerak baik yang bersifat terbuka atau tertutup sangat diperlukan untuk melaksanakan berbagai aktifitas, seiring perkembangan kota yang semakin meningkat secara pesat dalam beberapa tahun terakhir. Namun terkadang perkembangan dan penataan bangunan yang ada tidak diimbangi dengan kesiapan infrastruktur bangunan maupun infrastruktur perkotaan. Sehingga semakin banyak bangunan, baik yang sudah lama berdiri maupun yang baru dibangun kurang memperhatikan perlindungan terhadap bahaya kebakaran. Bahaya kebakaran dapat terjadi pada bangunan atau lokasi dimana bangunan itu berada.

Kebakaran adalah bahaya yang diakibatkan oleh adanya ancaman potensial berupa percikan api sejak awal terjadinya api hingga penjalaran api dan asap lalu gas yang ditimbulkan (Badan Standarisasi Nasional Indonesia, 2000). Saat terjadi kebakaran, api timbul sebagai reaksi proses rantai antara bahan mudah terbakar (fuel), oksigen $\left(\mathrm{O}_{2}\right)$, dan panas (heat) yang sering disebut segitiga api (fire triangle). Sampai salah satu elemen pembentuk api berakhir, rangkaian proses oksidasi akan terus berlangsung, dan untuk mencegah terjadiya api, maka salah satu komponen tersebut harus dihindari/ diputus.

Kampus menurut KBBI (Kamus Besar Bahasa Indonesia), diacu dalam Danang (2016: 16) adalah daerah lingkungan bangunan utama perguruan tinggi (universitas, akademi) tempat semua kegiatan belajar- mengajar dan administrasi berlangsung. Sedangkan dalam pengertian modern, kampus berarti, sebuah kompleks atau daerah tertutup yang merupakan kumpulan gedung- gedung universitas atau perguruan tinggi. Di kampus banyak kegiatan sosial berlangsung, bukan hanya kegiatan akademik dan administratif saja. Selain kegiatan belajar mengajar yang sudah pasti ada, ada juga kegiatan administratif yang selalu terkait. Kemudian interaksi antar mahasiswa berupa kegiatan sosial. Kampus juga terdiri dari bermacam- macam orang dengan bermacam- macam kepentingan. 
Beragamnya kegiatan yang tejadi di dalam lingkungan kampus membuat kampus menjadi daerah yang sangat rawan terjadinya bencana kebakaran. Ditambah lagi banyaknya resiko yang bisa ditimbulkan oleh benda- benda dan aktivitas seseorang (manusia) yang ada dikampus. Mulai dari gas dikantin, kemudian laboratorium yang menyimpan berbagai zat kimia, ada juga listrik yang memang selalu menjadi ancaman utama penyebab kebakaran, serta juga seseorang (manusia) yang membuang putung rokok sebarangan yang dimana putung rokok tersebut masih ada bara apinya.

Dikampus A Universitas Negeri Jakarta sendiri terdapat beberapa bangunan yang menjulang tinggi dengan ketinggi lebih dari empat lantai. Yang terbaru ada gedung kembar Dewi Sartika dan RA Kartini, kemudian gedung M. Syafei, lalu gedung Pusat Studi dan Sertifikasi Guru, gedung UPT Perpustakaan, dan juga Gedung Parkiran Sepeda Motor yang belum seutuhnya jadi namun sudah dipergunakan untuk memarkirkan kendaraan bermotor. Gedung- gedung tersebut tentunya harus memiliki sistem proteksi dan keselamatan kebakaran yang sesuai dengan peraturan yang ada. Sebab terjadinya kebakaran dalam gedung perkuliahan ataupun parkiran dapat mengakibatkan berbagai macam hal yang tidak diinginkan baik terhadap kerugian harta benda maupun korban jiwa, bahkan kehilangan data- data penting terhentinya proses perkuliahan dan lingkungan menjadi tidak kondusif.

Pengertian parkir menurut Warpani dalam bukunya yang berjudul, "Merencanakan Sistem Pengangkutan”, diacu dalam Kusyanto (2005) adalah suatu saat dimana kendaraan harus berhenti untuk sementara (menurukan muatan) atau berhenti cukup lama. Sehingga tempat parkir harus ada pada saat terakhir atau apabila tujuan perjalanan sudah tercapai sebab suatu kendaraan tidak mungkin berjalan terus menerus.

Universitas Negeri Jakarta (UNJ) adalah sebuah universitas negeri yang menjadi andalan kota Jakarta. Setting ruang kampus yang telah ada ini, dalam perkembangan proses belajar mengajar memberikan dampak dalam penyediaan ruang parkir bagi mahasiswa dan civitas akademika kampus, apalagi dengan pertambahan jumlah mahasiswa setiap tahunnya, menuntut tersedianya ruang parkir yang memadai dan dapat menampung semua kendaraan yang akan menggunakan fasilitas tersebut. Namun, melihat kondisi bangunan parkiran depan Kampus A Universitas Negeri Jakarta yang pembangunan tersendat tetapi sudah dipergunakan untuk khayalayak di khawatirkan dapat membahayakan penghuni, dan karyawan yang bekerja di gedung parkiran tersebut apabila terjadi kebakaran.
Saat ini ada aplikasi yang dipakai untuk mengetahui karakteristik penyebaran api ketika terjadi kebakaran disuatu ruangan. Langkah ini sangat menguntungkan karena dapat mengetahui bagaimana penyebaran api saat terjadi kebakaran dan seberapa bahaya kebakaran yang disimulasikan. Dengan adanya fire modelling ini dapat menjadi pendekatan enginering praktis untuk memberikan peninjauan tambahan terhadap aspek keselamatan kebakaran pada gedung parkiran kampus A Univeristas Negeri Jakarta.

\section{Tujuan Penelitian}

Tujuan umum penelitian ini adalah:

1. Untuk mengetahui pergerakan serta perkembangan api dari hasil simulasi kebakaran dengan menggunakan software FDS pada gedung parkir Kampus A Universitas Negeri Jakarta.

2. Untuk mengetahui seberapa bahaya kebakaran yang disimulasikan.

\section{METODOLOGI PENELITIAN Tempat, Waktu dan Subjek Penelitian}

Penelitian ini dilakukan di Parkiran Kampus A Universitas Negeri Jakarta yang terletak dijalan Rawamangun Muka Jakarta Timur. Waktu yang digunakan pada penelitian ini di Bulan AprilJuni 2016.

\section{Alat dan Bahan Penelitian}

\section{Alat Penelitian}

Alat penelitian ini memakai alat yang terdiri dari hardware dan software.

Adapun rinciannya sebagai berikut:

1. Hardware yang digunakan adalah:

- Processor Intel Core Duo (2.20 GHz),

- Besar memori RAM 4.0 GB,

- Kapasitas Harddisk 320 GB,

- Monitor

- Perangkat mouse dan keyboard standar

- Printer

2. Software yang digunakan adalah:

- $\quad$ Sistem Operasi Microsoft Windows 7

- $\quad$ Microsoft Office 2007

- Software FDS versi 5.0 untuk alat simulasi

- $\quad$ Text editor Notepad++

- Program Command Prompt

- Web Browser Google Chrome dan Mozila Firefox

3. Anemometer 
Bahan

Bahan- bahan yang digunakan pada saat penelitian adalah sebagai berikut:

1. Data- data terkait bangunan gedung parkir sepeda motor Kampus A Universitas Negeri Jakarta.

2. Literature dan jurnal- jurnal penelitian sebelumnya yang berupa buku, maupun jurnal online yang berkaitan dengan penelitian dan khususnya yang berkaitan dengan fire modelling dengan perangkat Fire Dynamics Simulator.

\section{Prosedur Pengumpulan Data \\ Studi Pustaka}

Melakukan pengumpulan data berdasarkan literature dan dokumen yang berhubungan dengan gedung parkir UNJ, proses pembakaran, perambatan api, laju produksi kalor, dan mempelajari penelitian terdahulu. Selain itu studi pustaka juga dengan menggunakan internet dan mencari dari berbagai sumber terpercaya.

\section{Simulasi}

Yaitu metode penelitian yang memperagakan sesuatu dalam bentuk tiruan yang mirip dengan keadaan yang sesunguhnya, simulasi juga yaitu penggambaran suatu sistem atau proses dengan peragaan memakai model statistik atau pameran (Pusat Bahasa Departemen Pendidikan Nasional, 2005). Peneliti menggunakan software Fire Dynamics Simulator Version 5.0 untuk melakukan simulasi kebakaran dengan pemodelan komputer.

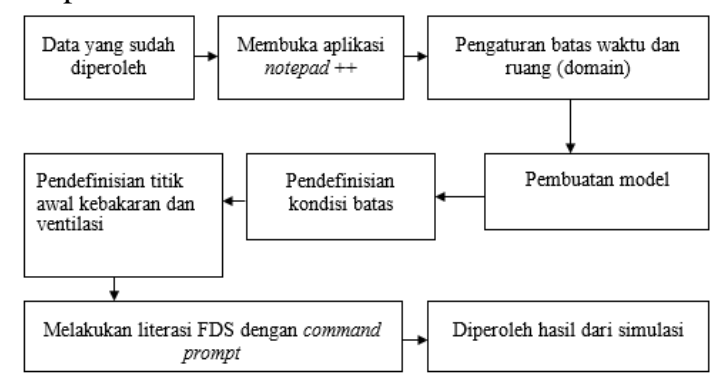

Gambar 1. Tahapan Analisis Data FDS

1) Menentukan batas waktu simulasi kebakaran dan menentukan domain serta ukuran grid.

2) Pembuatan model geometri bangunan dan benda atau sepeda motor.

3) Pendefinisian kondisi batas yaitu memasukkan data-data terkait dengan material properties.

4) Pendefinisian titik awal kebakaran dan ventilasi yaitu memasukkan besarnya Heat Release Rate per Unit Area (HRRPUA) sebagai api dan velocity sebagai kecepatan angin setelah itu dapat ditentukan titik atau tempat terjadinya api awal dan ventilasi atau bukaan pada bangunan.

5) Melakukan literasi FDS dengan menggunakan command prompt.

6) Diperoleh output dari simulasi FDS, beberapa data keluaran yang dipakai adalah laju pelepasan panas, burning rate, gambar visual, serta suhu maksimum.

Tabel 1. Simulasi Berdasarkan Arah Angin dan Titik Awal Api

\begin{tabular}{|c|c|c|c|c|}
\hline & & Arah Angin & $\begin{array}{c}\text { Kecepatan } \\
\text { Angin }\end{array}$ & Titik Awal Api \\
\hline \multirow[t]{3}{*}{ Simulasi 1} & Simulasi 1.1 & $\begin{array}{c}\text { Dari sumbu } \mathrm{X} \\
\min \end{array}$ & $0.9 \mathrm{~m} / \mathrm{s}$ & $\begin{array}{c}\text { Disudut ruangan } \\
\text { dengan adanya bukaan }\end{array}$ \\
\hline & Simulasi 1.2 & $\begin{array}{c}\text { Dari sumbu X } \\
\text { min }\end{array}$ & $0.9 \mathrm{~m} / \mathrm{s}$ & $\begin{array}{l}\text { Diantara motor tengah } \\
\text { ruangan }\end{array}$ \\
\hline & Simulasi 1.3 & $\begin{array}{l}\text { Dari sumbu } X \\
\min \end{array}$ & $0.9 \mathrm{~m} / \mathrm{s}$ & $\begin{array}{l}\text { Diantara motor yang } \\
\text { dekat dengan dinding } \\
\text { tanpa adanya bukaan }\end{array}$ \\
\hline \multirow[t]{3}{*}{ Simulasi 2} & Simulasi 2.1 & $\begin{array}{l}\text { Dari sumbu X } \\
\max \end{array}$ & $1.0 \mathrm{~m} / \mathrm{s}$ & $\begin{array}{c}\text { Disudut ruangan } \\
\text { dengan adanya bukaan }\end{array}$ \\
\hline & Simulasi 2.2 & $\begin{array}{l}\text { Dari sumbu X } \\
\max \end{array}$ & $1.0 \mathrm{~m} / \mathrm{s}$ & $\begin{array}{l}\text { Diantara motor tengah } \\
\text { ruangan }\end{array}$ \\
\hline & Simulasi 2.3 & $\begin{array}{l}\text { Dari sumbu } X \\
\max \end{array}$ & $1.0 \mathrm{~m} / \mathrm{s}$ & $\begin{array}{l}\text { Diantara motor yang } \\
\text { dekat dengan dinding } \\
\text { tanpa adanya bukaan }\end{array}$ \\
\hline \multirow[t]{3}{*}{ Simulasi 3} & Simulasi 3.1 & $\begin{array}{c}\text { Dari sumbu } Y \\
\text { min }\end{array}$ & $0.6 \mathrm{~m} / \mathrm{s}$ & $\begin{array}{c}\text { Disudut ruangan } \\
\text { dengan adanya bukaan }\end{array}$ \\
\hline & Simulasi 3.2 & $\begin{array}{c}\text { Dari sumbu } Y \\
\text { min }\end{array}$ & $0.6 \mathrm{~m} / \mathrm{s}$ & $\begin{array}{l}\text { Diantara motor tengah } \\
\text { ruangan }\end{array}$ \\
\hline & Simulasi 3.3 & $\begin{array}{l}\text { Dari sumbu Y } \\
\min \end{array}$ & $0.6 \mathrm{~m} / \mathrm{s}$ & $\begin{array}{l}\text { Diantara motor yang } \\
\text { dekat dengan dinding } \\
\text { tanpa adanya bukaan }\end{array}$ \\
\hline \multirow[t]{3}{*}{ Simulasi 4} & Simulasi 4.1 & $\begin{array}{l}\text { Dari sumbu } X \\
\text { min, } X \max , Y \\
\text { min }\end{array}$ & $\begin{array}{c}(0.9,1.0,0.6) \\
\mathrm{m} / \mathrm{s}\end{array}$ & $\begin{array}{c}\text { Disudut ruangan } \\
\text { dengan adanya bukaan }\end{array}$ \\
\hline & Simulasi 4.2 & $\begin{array}{l}\text { Dari sumbu } X \\
\text { min, } X \max , Y \\
\text { min }\end{array}$ & $\begin{array}{c}(0.9,1.0,0.6) \\
\mathrm{m} / \mathrm{s}\end{array}$ & $\begin{array}{l}\text { Diantara motor tengah } \\
\text { ruangan }\end{array}$ \\
\hline & Simulasi 4.3 & $\begin{array}{c}\text { Dari sumbu X } \\
\text { min, X max, Y } \\
\text { min }\end{array}$ & $\begin{array}{c}(0.9,1.0,0.6) \\
\mathrm{m} / \mathrm{s}\end{array}$ & $\begin{array}{l}\text { Diantara motor yang } \\
\text { dekat dengan dinding } \\
\text { tanpa adanya bukaan }\end{array}$ \\
\hline
\end{tabular}

\section{HASIL PENELITIAN}

\section{Pengamatan Visual}

Pada bagian ini, peneliti mengamati setiap perkembangan dan penyebaran api pada setiap simulasi. Pada pengamatan visual, terlihat titik awal api yang berada di sudut ruangan lebih lama menyebar dari pada titik awal api yang berada ditengah ruangan dan diantara motor dekat dengan dinding tanpa adanya bukaan. Selain itu penyebaran api pada angin yang datang dari tiga arah, yakni dari sumbu $\mathrm{x}$ max, $\mathrm{x}$ min, dan $\mathrm{y}$ min lebih cepat menyebar dari pada penyebaran api dari satu arah. Rata-rata dari setiap simulasi arah penyebaran api pada awalnya mengikuti arah angin, lalu pada akhirnya menyebar kesegala arah mengikuti arah material bakar dan ke arah bukaan.

\section{Analisa Waktu Penyalaan (Time To Ignition)}

Waktu penyalaan ialah waktu dimana temperatur telah melewati ambang batas temperatur penyalaan. Pengukuran nilai dari time to ignition $\left(\mathrm{t}_{\mathrm{ig}}\right)$ dalam penelitian ini dilakukan dengan cara memperhatikan karakteristik dari laju produksi kalor (Heat Release Ratel HRR) yang terjadi. Sesuai dengan apa yang telah dijelaskan dalam dasar teori, suatu material yang mengalami eksotermik atau dalam keadaan terbakar, pasti memiliki nilai kalor yang dilepaskan dari material tersebut per satuan waktu, yang direpresentasikan dalam nilai HRR. 
Dengan demikian bila kita memiliki kurva HRR dari material yang sedang terbakar, dapat diketahui waktu penyalaannya dari kurva tersebut, yakni ketika nila HRR mulai naik. Berdasarkan hasil yang diperoleh dari pemodelan, didapatkan hasil pola laju pelepasan kalor untuk berbagai orientasi, arah angin dan titik awal nyala api. Berikut ini akan dibahas pengaruh dari masing- masing variabel tersebut terhadap kurva laju pelepasan kalor dimana $t_{\text {ig }}$ akan ditentukan dari kurva tersebut.

\section{Pengaruh Titik Awal Nyala Api terhadap Waktu Penyalaan}

Grafik di bawah merupakan grafik Laju Pelepasan Kalor/ Heat Release Rate (HRR) dalam $\mathrm{kW}$. Perbedaan warna dalam kurva mengindikasikan perbedaan titik awal nyala api.

1. Grafik HRR Simulasi 1

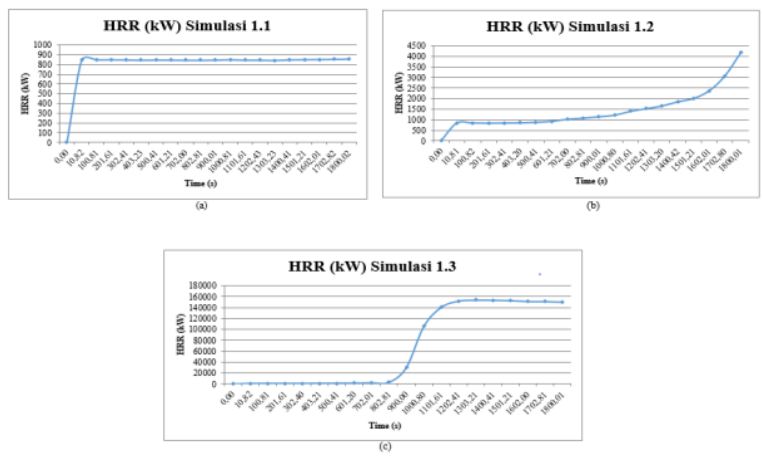

Gambar 2. Grafik Laju Pelepasan Kalor (a) Simulasi 1.1 (b) Simulasi 1.2 (c) Simulasi 1.3

Dilihat dari grafik HRR simulasi 1.1 terlihat bahwa kenaikan HRR sangat sedikit. Pada simulasi 1.2 grafik HRR terlihat pola umum yakni mendatar selama beberapa puluh detik, HRR naik secara perlahan dan terus meningkat pada detik ke 1000 . Berbeda halnya dengan simulasi 1.3 , pola HRR terlihat mendatar hingga detik ke 800, lalu naik dengan curam sampai puncak kurva, lalu pada detik ke 1400 turun secara perlahan. Pada periode ini nyala api dari simulasi 1.3 terlihat relatif lebih besar dari simulasi 1.1 dan simulasi 1.2. Proses pembakaran pada simulasi 1.3 dengan nyala api yang besar tersebut maka tingkat kemampuan membakarnya juga semakin besar. Grafik dari tingkat kemampuan membakar material untuk data diatas dapat dilihat berikut ini.

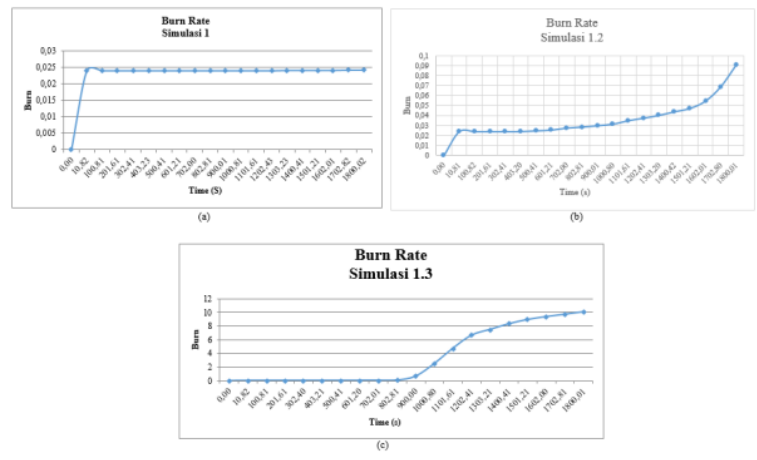

Gambar 3. Grafik Burn Rate (a) Simulasi 1.1 (b) Simulasi 1.2 (c) Simulasi 1.3

Dari ketiga kurva di grafik HRR, untuk titik awal api berada ditengah ruangan terlihat naik lebih dulu, seperti yang telah dibahas pada sub bab sebelumnya hal ini dikarenakan pengaruh konveksi pada material polymer polyethilene yang berada ditengah ruangan dan didekat dinding tanpa adanya bukaan jauh lebih besar dibandingkan dengan yang berada disudut ruangan. HRR pada simulasi 1.3 jauh lebih tinggi dibandingkan pada simulasi 1.1. HRR pada simulasi 1.2 naik secara perlahan. HRR merupakan fungsi dari luas permukaan api, sehingga untuk api yang lebih besar maka HRRya juga akan menunjukkan nilai terbesar pula. Untuk tingkat kemampuan membakar dalam berbagai titik awal nyala api, tampak terendah pada simulasi 1.1. hal ini dikarenakan titik awal nyala api pada simulasi 1.1 terkena pengaruh konveksi yang hampir sama, sehingga waktu terbakarnya tiap titik hampir sama. Demikian pengaruhi angin yang juga menjadi salah satu faktor, arah api yang terlihat pada pengamatan visual terlihat bahwa api searah dengan arah angin serta material yang terletak dibaris kedua dari titik nyala api juga terbilang jauh.

2. Grafik HRR Simulasi 2

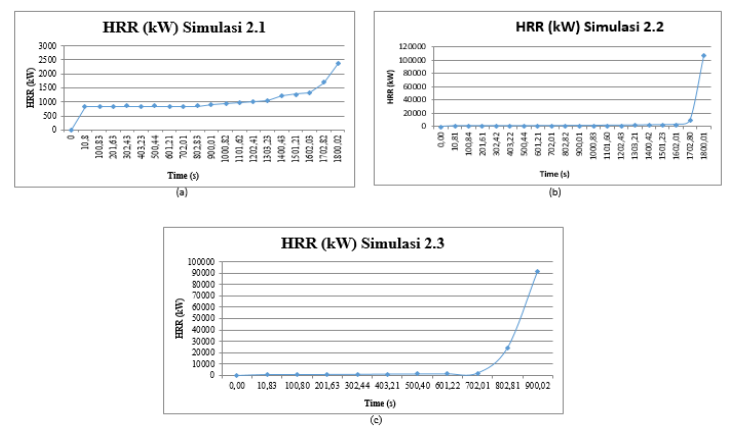

Gambar 4. Grafik Laju Pelepasan Kalor (a) Simulasi 2.1 (b) Simulasi 2.2 (c) Simulasi 2.3 
Dilihat dari grafik HRR simulasi 2.1 terlihat pola mendatar selama beberapa ratus detik, lalu naik dengan curam pada detik ke 1000. Pada simulasi 2.3 tampak bahwa HRR naik dengan curam pada detik ke 700, yang menandakan bahwa tingkat kebakaran semakin besar pada detik tersebut dalam berada pada puncak didetik ke 900. Lain lagi pada simulasi 2.2, bahwa puncak tertinggi HRR terjadi di detik ke 1800. Semakin tinggi nilai HRR yang didapatkan pada suatu simulasi maka kemampuan membakar material juga semakin membesar. Berikut grafik laju kemampuan membakar pada simulasi 2.

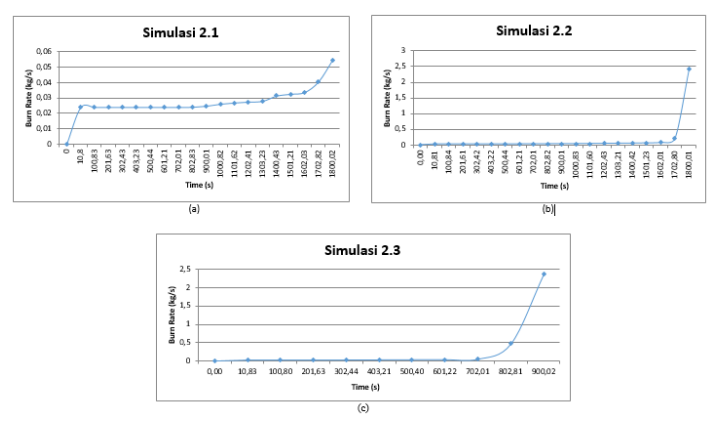

Gambar 5. Grafik Burn Rate (a) Simulasi 2.1 (b) Simulasi 2.2 (c) Simulasi 2.3

Dari ketiga kurva HRR, untuk titik awal api berada diantara motor dekat dinding tanpa adanya bukaan terlihat naik terlebih dahulu, pada detik 900 nilai HRR sudah naik dengan drastis, hal ini menandakan bahwa tingkat kemampuan membakar juga semakin membesar pada detik tersebut. Tingkat kemampuan membakar yang terendah pada simulasi 2 ini ada pada simulasi 2.1. Pada simulasi 2.1 terlihat bahwa tingkat kemampuan membakarnya sampai detik ke 1000 berada diantaras $0,0239 \mathrm{~kg} / \mathrm{s}$ $0,02607 \mathrm{~kg} / \mathrm{s}$, sedangkan pada simulasi 2.2 terlihat pola mendatar hingga detik ke 1700, tingkat kemampuan membakar pada detik tersebut berkisar antara $0,0239 \mathrm{~kg} / \mathrm{s}-0,2006 \mathrm{~kg} / \mathrm{s}$ dan naik secara drastis pada detik ke 1800 kemampuan membakar mencapai $2,4057 \mathrm{~kg} / \mathrm{s}$. Sama hal pada simulasi 1.3 terlihat grafik mendatar pada beberapa ratus detik, kemampuan membakar naik drastis pada detik ke 900 mencapai 2,379 kg/s. Padahal kemampuan membakar pada detik ke 10 - 800 berata diantara $0,0239 \mathrm{~kg} / \mathrm{s}-0.4701 \mathrm{~kg} / \mathrm{s}$.
3. Grafik HRR Simulasi 3

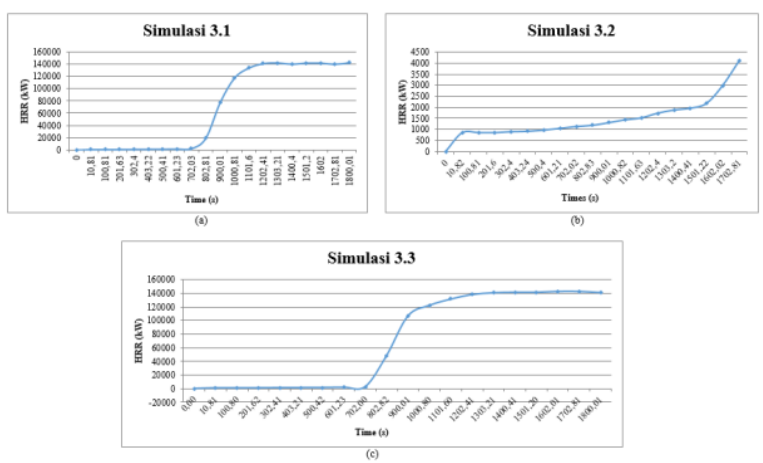

Gambar 6. Grafik Laju Pelepasan Kalor (a) Simulasi 3.1 (b) Simulasi 3.2 (c) Simulasi 3.3

Pada grafik HRR simulasi 3 terlihat perbedaan kenaikan laju perpindahan kalor pada setiap simulasinya. Pada simulasi 3.1 nilai HRR pada mulanya naik dengan perlahan antara 837,39 kW- 1531,6 Kw, lalu pada detik ke 1000 naik dengan drastis mencapai $77677,1 \mathrm{~kW}$. Pada simulasi 3.2 tidak ada kenaikan secara drastis dan cenderung stabil. Beda halnya pada simulasi 3.3, terlihat bahwa ada kenaikan drastis pada detik ke 700 lalu naik secara stabil pada hingga detik ke 1600 . Pada detik ke 1600 nilai HRR yang diperoleh mencapai $142961,3 \mathrm{~kW}$, lalu mengalami penurunan pada detik ke 1700 sebanyak $8.1 \mathrm{~kW}$. Pada setiap kenaikan dan penurunan HRR juga menandakan kemampuan membakar ketika terjadi kebakaran pada material tersebut. Berikut grafik burning rate untuk simulasi 3.

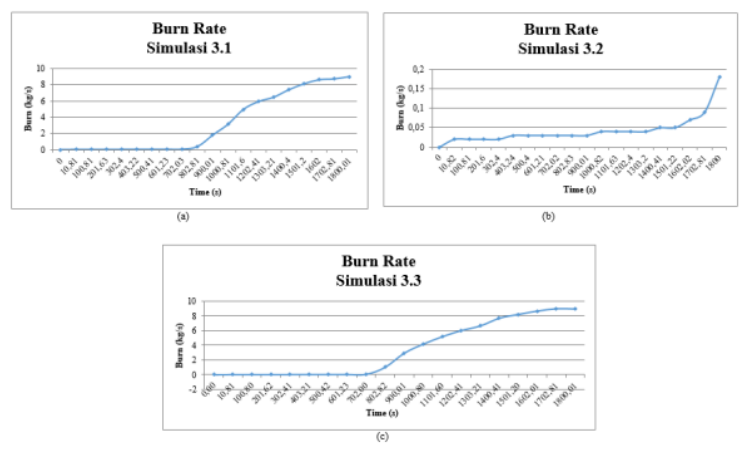

Gambar 7. Grafik Burn Rate (a) Simulasi 3.1 (b) Simulasi 3.2 (c) Simulasi 3.3 
Pada grafik simulasi 3.1 terlihat kemampuan membakar material terlihat sangat rendah hingga detik ke 800, kemampuan membakar dari detik awal hingga detik ke 800 sebesar $0,02 \mathrm{~kg} / \mathrm{s}-0.38 \mathrm{~kg} / \mathrm{s}$, lalu naik secara bertahap hingga detik ke 1400 , kenaikan setiap detiknya sebesar $1.0 \mathrm{~kg} / \mathrm{s}$. Pada detik ke 1500, mengalami pelambatan kemampuan bakar. Pada detik 1500 kemampuan membakar sebesar 8,1 $\mathrm{kg} / \mathrm{s}$ lalu pada setiap detik berikutnya naik hanya sebesar $0.5 \mathrm{~kg} / \mathrm{s}$. Simulasi 3.2 terlihat bahwa kenaikan burning ratenya sangat lambat dan kecil, terlihat bahwa kenaikan kemampuan membakar setiap detik pada simulasi 3.2 hanya sebesar 0.02 $\mathrm{kg} / \mathrm{s}$. Pada grafik simulasi 3.3 terlihat bahwa kenaikan HRR terjadi pada detik ke 700, berarti menandakan bahwa kemampuan membakar material juga naik pada detik tersebut. Semakin besar nilai HRR maka semakin besar pula api yang ditimbulkan dan semakin besar pula kemampuan dalam menghabiskan material yang dibakar.

\section{Grafik HRR Simulasi 4}

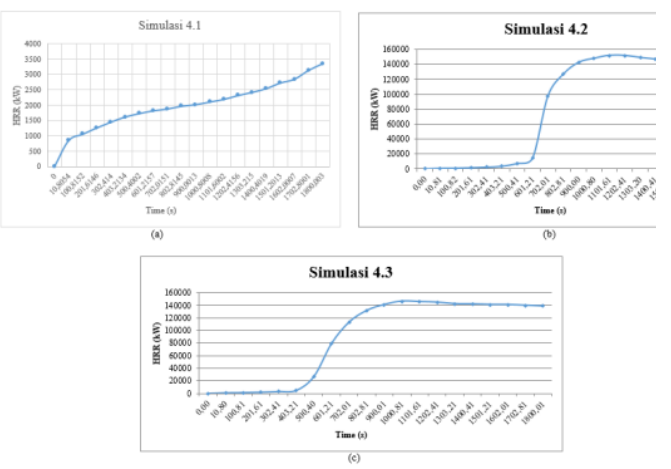

Gambar 8. Grafik Laju Pelepasan Kalor (a) Simulasi 4.1 (b) Simulasi 4.2 (c) Simulasi 4.3

Pada grafik diatas terlihat grafik HRR simulasi 4.1 naik secara bertahap, tidak ada kenaikan yang drastis. Kenaikan HRR pada setiap detiknya sebesar $\pm 200 \mathrm{~kW}$. Pada simulasi 4.2 terlihat grafik HRR yang mendatar, kenaikan nilai HRR sangat kecil hingga detik ke 600, lalu pada simulasi 4.2 nilai HRR mengalami kenaikan yang cukup drastis pada detik ke 700 yaitu sebesar 97740,4 kW. Nilai HRR terus mengalami kenaikan secara bertahap hingga detik ke 1200 , nilai HRR pada detik tersebut mencapai $151628 \mathrm{~kW}$ lalu mengalami penurunan secara bertahap pada detik ke 1300. Simulasi 4.3 juga terlihat grafik yang mengalami kenaikan sedikit hingga detik ke 400, lalu mengalami kenaikan yang drastis pada detik 700. Puncak kenaikan HRR berada pada detik ke 1000 yaitu sebesar 144717,8 kW, lalu mengalami penurunan HRR pada detik berikutnya secara bertahap sebesar $\pm 2 \mathrm{~kW}$. Pada setiap kenaikan dan penurunan HRR juga menandakan kemampuan membakar ketika terjadi kebakaran pada material tersebut. Berikut grafik burning rate untuk simulasi 4.

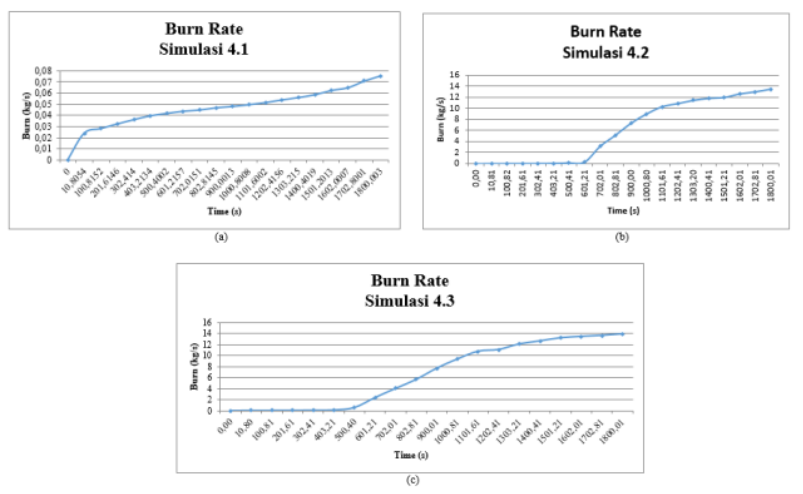

Gambar 9. Grafik Burn Rate (a) Simulasi 4.1 (b) Simulasi 4.2 (c) Simulasi 4.3

Pada gambar diatas terlihat grafik HRR yang berbeda pada setiap simulasinya. Terlihat pada simulasi 4.1 grafik terus mengalami kenaikan secara bertahap, hanya kemampuan membakar pada simulasi 4.1 tidak terlalu besar seperti simulasi 4.2 dan simulasi 4.3, kenaikan burning rate pada simulasi 4.1 hanya sebesar $\pm 0.01 \mathrm{~kg} / \mathrm{s}$ setiap detiknya. Pada simulasi 4.2, kenaikan burning rate pada detik awal hingga detik ke 600 mengalami kenaikan yang sangat kecil, yaitu antara 0,00239 $\mathrm{kg} / \mathrm{s}-0,2971 \mathrm{~kg} / \mathrm{s}$. lalu pada detik ke 700 mengalami kenaikan yang cukup tinggi yaitu sebesar 3,1385 $\mathrm{kg} / \mathrm{s}$. Simulasi 4.3 kenaikan burning rate sangat cepat, pada detik detik ke 500 sudah terlihat kenaikan yang cukup tinggi. Burning rate simulasi 4.3 hingga detik ke 1800 mencapai $13 \mathrm{~kg} / \mathrm{s}$.

\section{Analisa Perpindahan Kalor}

Pada sub ini penulis akan membahas mengenai perpindahan kalor pada setiap simulasi. Pada dasarnya perpindahan kalor merupakan energi yang berpindah akibat adanya perbedaan temperatur. Seperti yang sudah dibahas pada bab sebelumnya bahwa terdapat tiga tipe perpindahan kalor, yakni konduksi, konveksi dan radiasi dimana ketiganya memiliki perananan masing- masing dalam proses terjadinya kebakaran.

Secara umum, perpindahan panas pada awal perkembangan segala jenis api hampir semua disebabkan karena konduksi. Selanjutnya, bila kebakaran mulai membesar, gas- gas panas mulai mengaliri benda- benda yang berada dijarak tertentu dari titik api dan ini juga diakibatkan oleh konduksi. Panas, yang berasal dari gas- gas yang berhubungan langsung dengan komponen- komponen bangunan atau yang berhubungan langsung dengan gabungan bahan bakar, dipindahkan kebenda tersebut melalui konduksi.

Pada bagian konveksi, ketika api membesar udara di sekitar menjadi panas karena konduksi. Udara panas dan produk- produk pembakaran mulai 
bermunculan. Perpindahan panas secara konveksi mengalir melalui pergerakan gas- gas. Ketika panas dipindahkan secara konveksi , ada pergerakan atau sirkulasi gas (yang akan mengalir dari suatu tempat ke tempat yang lain. Seperti halnya dengan perpindahan panas, airan panas tersebut berasal dari tempat yang lebih panas menuju tempat yang lebih dingin.

Radiasi meyebarkan panas sebagai gelombang elektromagnetik tanpa kehadiran penghantar. Karena merupakan suatu gelombang elektromagnetik, energi tersebut bergerak dalam bentuk garis lurus dengan kecepatan cahaya. Semua benda yang panas akan menyebarkan panas. Radiasi merupakan penyebab utama terjadinya kebakaran (api yang menyala pada gabungan bahan bakar atau bangunan- bangunan yang berada jauh dari bahanbahan bakar). Ketika api mulai membesar, api itu menyebarkan lebih banyak energi dalam bentuk panas. Dalam kebakaran besar, sangat mungkin atau kelompok bahan bakar lain yang berada dijarak yang agak jauh. Energi panas yang dipancarkan secara radiasi,bergerak melalui ruang- ruang hampa dan ruang- ruang yang berisi zat gas yang biasamya dapat menghambat konduksi dan konveksi. Materimateri yang memantulkan energi yang telah teradiasi akan menghambat penyebaran panas.

\section{Simulasi 1}

Pada simulasi 1, arah angin berasal dari sumbu $\mathrm{x}$ min dengan kecepatan $0.9 \mathrm{~m} / \mathrm{s}$. Ada tiga titik yang akan diujikan karakteristik penyebaran api pada simulasi ini, yakni simulasi 1.1 titik awal nyala api berada disudut ruangan dengan adanya bukaan, simulasi 1.2 titik awal api berada diantara motor tengah ruangan, dan simulasi 1.3 berada diantara motor dekat dengan dinding tanpa adanya bukaan.

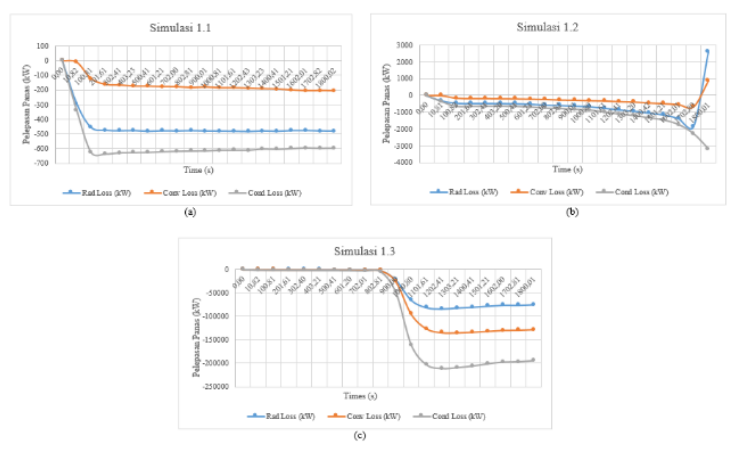

Gambar 4.46. Grafik Perpindahan Panas (a) Simulasi 1.1 (b) Simulasi 1.2 (c) Simulasi 1.3

Terilihat pada grafik 4.46, bahwa perpindahan panas secara konduksi terbesar ada pada simulasi 1.3. Pada detik ke 10 hingga detik ke 800 , perpindahan panas yang terjadi antara 379,067 $\mathrm{kW}-1324,65 \mathrm{~kW}$, lalu mengalami pelepasan panas secara signifikan pada detik ke 1000 hingga detik ke 1400, lalu perpindahan panas tersebut berkurang pada detik ke 1500 hingga 1800. Pada simulasi 1.2, perpindahan panas secara konduksi terus mengalami penurunan secara stabil, panas yang dipindahkan dari detik awal hingga detik ke 1800 berkisar antara 365,088 kW - 2289,11 kW. Perpindahan panas secara konduksi pada simulasi 1.1 sangat kecil. Pada titik awal hingga detik ke 1500 mengalami perpindahan panas antara 338, $514 \mathrm{~kW}-600,437$ $\mathrm{kW}$, dan mengalami penurunan pada detik ke 1600 .

Pada perpindahan panas secara konduksi terlihat juga pada simulasi 1.3 mengalami perpindahan panas lebih besar, seperti yang telah dijelaskan sebelumnya, ketika api telah mulai membesar, api itu menyebarkan lebih banyak energi dalam bentuk panas. Dalam kebakaran besar, sangat mungkin atau kelompok bahan bakar lain yang berada dijarak yang agak jauh. Berbeda halnya pada simulasi 1.1 dan simulasi 1.2, perpindahan panas secara konduksi lebih kecil.

2. Pada simulasi 2,

Pada Simulasi 2, arah angin berasal dari sumbu x max dengan kecepatan $1.0 \mathrm{~m} / \mathrm{s}$. Ada tiga titik yang akan diujikan karakteristik penyebaran api pada simulasi ini, yakni simulasi 2.1 titik awal nyala api berada disudut ruangan dengan adanya bukaan, simulasi 2.2 titik awal api berada diantara motor tengah ruangan, dan simulasi 2.3 berada diantara motor dekat dengan dinding tanpa adanya bukaan.

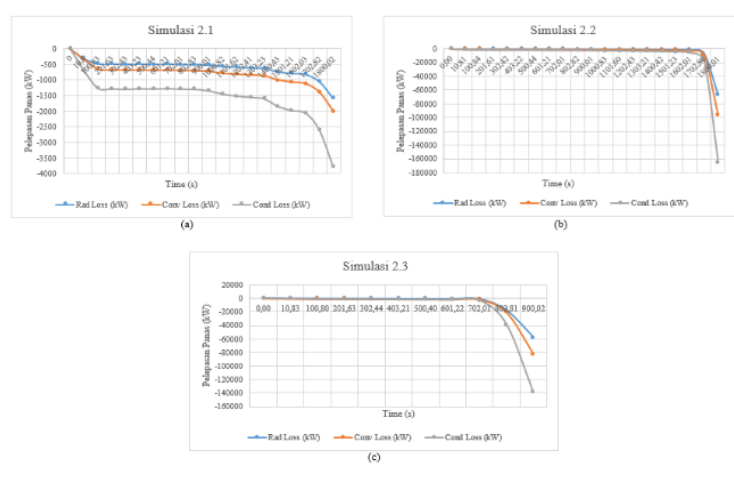

Gambar 4.47. Grafik Perpindahan Panas (: Simulasi 2.1 (b) Simulasi 2.2 ( Simulasi 2.3

Pada grafik 4.47 perpindahan panas simulasi 2, terlihat bahwa konduksi mempunyai nilai yang lebih besar. Pada simulalsi 2.1 perpindahan panas secara konduksi terus mengalami kenaikan secara bertahap, begitu pula dengan konveksi dan radiasi. Berbeda halnya pada simulasi 2.2 dan simulasi 2.3 bahwa ada beberapa beberapa detik konveksi dan radiasi terlihat bergerak sangat kecil dan naik secara signifikan pada beberapa detik kemudian. 


\section{Simulasi 3}

Pada simulasi 3, arah angin berasal dari sumbu y min dengan kecepatan $0.6 \mathrm{~m} / \mathrm{s}$. Ada tiga titik yang akan diujikan karakteristik penyebaran api pada simulasi ini, yakni simulasi 3.1 titik awal nyala api berada disudut ruangan dengan adanya bukaan, simulasi 3.2 titik awal api berada diantara motor tengah ruangan, dan simulasi 3.3 berada diantara motor dekat dengan dinding tanpa adanya bukaan.

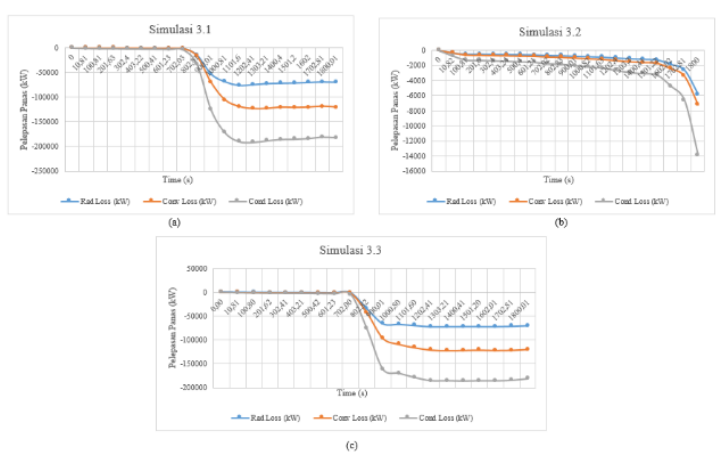

Gambar 4.48. Grafik Perpindahan Panas (a) Simulasi 3.1 (b) Simulasi 3.2 (c) Simulasi 3.3

Pada simulasi 3 ini, pengaruh konduksi sangat berpengaruh. Pada setiap simulasi, arah angin berasal dari sumbu y min, dimana pada pengamatan visual, bahwa api menyebar mengikuti arah angin. Terlihat pada simulasi 3.1, dimana titik awal api berasal dari sudut ruangan dekat dengan bukaan. Dikarenakan arah angin berasal dari sumbu y min dan apipun bergerak mengikuti arah angin, maka dengannya mudahnya api merambat kebenda yang ada didepannya dikarenakan jarak yang dekat. Setelah api membesar, api menyebar karena adanya faktor konveksi dan radiasi yang besar pula. Begitu juga pada simulasi 3.2 dan simulasi 3.3.

\section{Simulasi 4}

Pada simulasi 4, arah angin berasal dari sumbu $\mathrm{x}$ min, $\mathrm{x}$ max dan $\mathrm{y}$ min dengan kecepatan pada sumbu x min sebesar $0.9 \mathrm{~m} / \mathrm{s}$, sumbu x max sebesar $1.0 \mathrm{~m} / \mathrm{s}$ dan y min sebesar $0.6 \mathrm{~m} / \mathrm{s}$. Ada tiga titik yang akan diujikan karakteristik penyebaran api pada simulasi ini, yakni simulasi 4.1 titik awal nyala api berada disudut ruangan dengan adanya bukaan, simulasi 4.2 titik awal api berada diantara motor tengah ruangan, dan simulasi 4.3 berada diantara motor dekat dengan dinding tanpa adanya bukaan.

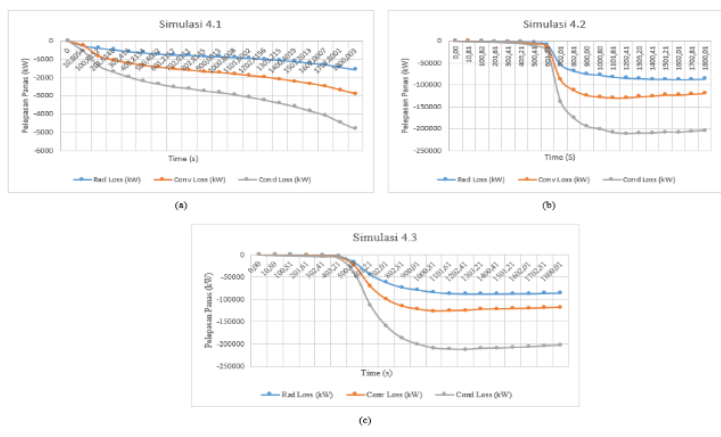

Gambar 4.49. Grafik Perpindahan Panas (a) Simulasi 4.1 (b) Simulasi 4.2 (c) Simulasi 4.3

Dapat dilihat pada gambar 4.49, pada simulasi 4 ini, perpindahan panas secara konduksi sangat berpengaruh, api sangat mudah menyebar karena faktor ini, selain itu perpindahan panas secara konveksi juga berpengaruh besar, hal ini disebabkan karena ada faktor pendukung lainnya, yaitu angin yang masuk dari segala arah.

\section{KESIMPULAN}

Kesimpulan yang dapat diambil dari hasil simulasi dengan menggunakan software Fire Dynamics Simulation 5.0 adalah sebagai berikut:

1. Penyebaran Api

a. Kecepatan penyebaran api pada simulasi 4 dimana arah angin dari segala arah jauh lebih tinggi dari arah angin yang hanya dari satu arah.

b. Kecepatan penyebaran api dengan lokasi titik awal api ditengah ruangan dan didekat dinding tanpa adanya bukaan lebih tinggi dari lokasi titik awal api yang berada disudut ruangan dengan satu arah angin.

c. Bahwa arah angin dan lokasi titik awal api mempengaruhi kecepatan penyebaran api.

d. Pada pengamatan visal penyebaran api pada awalnya searah dengan arah angin, lalu kemudian menyebar kesegala arah mengikuti material bakar dan ke arah bukaan.

e. Penyebaran panas secara konduksi dan konveksi akan berbeda dengan bentuk nyatanya, karena bentuk motor pada nyatanya tidak rata seperti yang dimodelkan pada simulasi, hanya saja penyebaran api akan terlihat tidak jauh berbeda pada nyatanya.

2. Bahaya Kebakaran yang Disimulasikan

a. Semakin besar nilai HRR maka semakin besar pula nilai burning rate yang didapatkan dan semakin besar pula tingkat kebakaran yang terjadi. 


\section{DAFTAR PUSTAKA}

Danang, E.P. (2016). Evaluasi Penerapan Keamanan dan Keselamatan Gedung Berbasis Metode CFSES (Computerized Fire Safety Evaluation System) pada Gedung Pusat Studi dan Sertifikasi Guru UNJ [Skripsi]. Jakarta: Fakultas Teknik, Universitas Negeri Jakarta,

Depdikbud. Kamus Besar Bahasa Indonesia. Jakarta: Balai Pustaka, 1996.

Ramli, S., (2010). Manajemen kebakaran. Jakarta, Indonesia: Dian Rakyat.

McGrattan, Kevin, et al. ( 2007) Fire Dynamics Simulator (Version 5.0) User Guide. National Institute of Standars and Tecnhnologi. USA.

McGrattan, Kevin, et al. (2007) Fire Dynamics Simulator (Version 5.0) Technical Reference Guide.. National Institute of Standars and Tecnhnologi. USA.

Kusyanto M., (2005): Studi Ruang Parkir Universitas Sultan Fatah (Unisfat) Demak. [jurnall. Demak: Fakultas Teknik, Universitas Sultasn Fatah. 